\title{
Using OVOP concept to achieve economic sustainability in the creative industry
}

\author{
Rora. P. Sari ${ }^{1, *}$ \\ ${ }^{1}$ Department of Business and Management, Faculty of Economics and Business, Padjadjaran University, Indonesia \\ *Corresponding author: rora.puspita@unpad.ac.id
}

ABSTRACT

Creative industry nowadays is considered to be one of the promising industries that can contribute significantly to one country's economics. Creative industry is very potential to be developed because the main resource of the industry is unlimited, since the main resource of the industry is the intellectual capital of the society. In Indonesia, the terms of creative industry was founded in 2005. The Indonesian creative industry forum was born from communities in Bandung. There are 15 sub-sectors in creative industry. If the municipality would like to develop all sub-sectors simultaneously, it will need a substantial amount of funds. The originality of this paper is that it will suggest developing the creative industry area with Bandung as an example by utilizing the OVOP (One Product One Village) concept.

The method used to make the point of analysis is the qualitative method. This research used literature study to analyze how OVOP concept might help Bandung to be more sustainable economically, in the terms of creative industry sector. Bandung municipality needs to make priority in order to achieve sustainability in the development of creative industry in the city. OVOP strategy can be implemented to make some areas to be more concentrated to produce certain products. The focus strategy in OVOP leads to unique product and service production that can be sold in the market, thus a unique value-added product will give a competitive advantage for the area. Having a competitive product will increase the income and economic sustainability for that particular area.

Keywords - creative industry, creative city, economic sustainability, OVOP concept.

\section{INTRODUCTION}

The creative economy has become a powerful transformative drive in the world nowadays. The potential of creative industry for development is vast and waiting to be withdrawn. Creative economy is one of the most rapidly growing sectors, not only in the GDP and income generation but also in job creations and exporting activities(1). In 2015, study by World Intellectual Property Organization (WIPO) in 45 countries concluded that creative industry has contributed over $7 \%$ in average for the total GDP in one country's economy (2). In the special edition of the United Nations Creative Economy Report, the world trade of creative goods and services put a value of US\$ 624 billion in 2011 and more than doubled from 2002 to 2011 (3). This fact shows that creative industry has the highest growth rather than any other industry in the world economy.

One reason that caused creative industry is such a potential sectors to be developed is because of the resources needed in it. Creative industry main resource is the intellectual capital, or the human capital of the industry itself. Human intellectual has no boundary, unlike other types of resources such as financial resource; creative industry has the basic of human creativity and idea building. The potential of growth and the human potential are the main reason why government need to pay attention to creative industry. Based on the creativity of the people, creative industry embodies the spirit of sustainable development, which recognized that people are the centre of sustainable development (4).

In Indonesia, the discussion about creative industry was started in 2005 among art communities in Bandung. Later in 2007, Bandung was nominated as the pilot project for the creative city for the Asia Pacific Region. The creative industry movement in Bandung occurred because there is collaboration between cultural, social, and economic activities (5). There was a real contribution of creative 
industry to the Bandung economy. In 2002, the GDP contribution from the creative sectors was $12.82 \%$, later it was increased to $14.46 \%$ in 2007 (6). It was predicted that the creative industry sectors GDP contribution to Bandung will keep increasing. But the next question is what the municipal should do to make the creative industry to be sustainable in the terms of growth and contribution for Bandung's economy?

\section{METHOD}

A city is a place for its citizens to have their daily activities, to make innovation and idea-building. Creativity is an important factor to develop a city (5). The creative industry was born from the city that has developed a good environment for the people to express their creativity. Creativity is not only about making money, but the outcome of one's creativity might resulted an economic implication that can be traded (4). In conclusion, a good city that supported creativity may gain a certain amount of economic impact back to the city itself. There are several ways to calculate the impact of creative industry to the city's economic. Indonesian Ministry of Trade mentioned that there are five main indicators to determine the economic contribution of creative economy, and they are: GDP basis, workforce basis, company's ratio basis, and international trade basis, and other basis (6). The complete list of the indicator can be seen in Table 1 .

Indonesia divided the creative industry into 15 subsectors. The 15 sub-sectors consists of: advertising ; architecture ; art and antiques market ; crafts ; design ; fashion ; video, film and photography ; interactive games ; music ; performing arts ; publishing ; computer and software ; radio and television ; research and development; culinary (7).

This paper used Bandung as the example on how to implement the solution-model to achieve economicsustainability within the creative industry. The unit analysis was districts in Bandung. This paper would explain the distribution of creative industry in each district using the 15 sub-sectors of creative industry. The This paper used only one economic contributor indicator as the point of analysis. The basis of company activity which is "the number of companies in the creative industries" was used as the basis data to determine the potential sub-sectors that needs to be developed within one district.

\section{RESULTS}

As the capital of West Java region, Bandung has a strategic role to boast the economic growth to the area around the city. Bandung has achieved around $8.62 \%$ economic growth during 2008-2012, and it was far above the average growth of Indonesian national growth that has $5.8 \%$ average score (8). Bandung has $1078 \mathrm{SME}$ who's engaged in creative industry (9). Table 2 provides a more detailed data of the distribution of creative industry SME in Bandung in each district. From Table 2, it can be seen that the sub-sectors that was developed in each Bandung district are varied and scattered. One district has more than one sub-sector that was developed by the citizen who lived in that area.

In Figure 1, it can be seen that there are three stages of supports that SME needs in order to implement OVOP in one particular district. Initial supports consists of the introduction of the OVOP concept, the basic of product development (technical support), the introduction of knowing the market of the product and knowledge of various distribution channels available (marketing support), the introduction of basic profit and loss calculation as well as financial access for SME (financial support), and the knowledge of legal aspect of the business (legal support).

Training support or intermediate support is consists of the next development of the technical aspect of the product, a more detailed marketing aspect like packaging and segmentation analysis, the more advance of financial calculation such as the concept of book keeping and a wider financial access introduction and strategy, and the introduction of all process of legal standing that needs to be done by the SME such as the requirement to form the business ownership and halal certification.

Lastly advance support is the highest form of support that the local government might give to the district and the SME itself. The advance technical support might be tailored according to the needs of each SME, the example of advance technical support is the knowledge of advance machinery to increase the efficiency of the product. As for advance marketing support, it can be in the form of exhibition and endorsement by the local government as well as the introduction of advertising, online social media and promotional concept. The advance financial support can be in the form of the introduction of financial report, financial ratio to analyse business performance and a more advance of support of financial access or 
government warrant so that SME will be able to get better additional capital for the business. Lastly, the legal advance support will be needed when the SME will depart to industrialized business. The legal requirement for industrial business will be more complex so that the SME needs the support such as government assistance to get the permit that the SME needed.

\section{DISCUSSION}

As the concept of OVOP emphasized the production of the same product from one specific village, the concept is also can be applied in the city region. But the village concept can be altered to the district (Kecamatan) levels and the one product concept can be widened to creative industry sub-sector. From table 2 , it can be seen that each district has variations in the terms of creative industry sub-sectors. For example, Cibeunying Kidul district, who has the highest number of SME, has 8 different sub-sectors that developed by the citizen in that area. Using the OVOP concept, one district should choose only one sector that has the most potential for the economy. If Bandung only applied the number of company as the indicator of the economic contribution of the creative industry to the city's total economy, Cibeunying Kidul district for example should choose craft sub-sectors to be the main sub-sectors to be developed in the area.

If we take Bandung as an example, several districts has applied OVOP, for example: Bandung has shoes central production in Cibaduyut, Bojongloa Kidul district; Bonsai plant production in Ujung Berung district; art lamps in Babakan Ciparay district; and Stone art in Sukamiskin district. The local government role is important to make a grand OVOP strategy sure each district will have different sub-sectors or product so that each district will have its own uniqueness and more sustain economically.

The strategy made by local government not only consists of the division of sub-sectors in each district, but also the support system sets by the government to make sure each district will achieve competitive advantage and economic sustainability. Using the concept that Haraguchi (2008) mentioned, support from the municipal as the steering committee is utterly important for SME to expand and develop its business. The four main supports from the local government need to be implemented to the creative industry entrepreneurs. The support model from the municipal to each district can be seen in Figure 1, where one district will have a particular support needs. Using the OVOP concept that one district will develop one sub-sector in creative industry; the supports need to be tailored per district as each district will have its own unique product. With OVOP, one district will have different legal, technical, marketing, and financial support. The stage of the support might also different. One more developed district might needs the support in the advance level, while the other might just started to develop one particular product, thus this district support level will be at the initial stage. One district might also need different support stage for different supports. For example, in one area, the entrepreneur may need marketing support at the initial stage (basic marketing support) while the technical support is on the advance level. It might happened when the product is already fully-developed, only needs regular update and innovation while the entrepreneur does not know who is the potential customer of the product.

For the next research, it is suggested that more indicator needs to be considered as the basis to choose which product that will be the main product of the district. To use a single indicator might lead to misleading decision as other indicator such as GDP contribution basis, workforce basis, and international trade basis might resulted in different decision in the terms of which subsectors that will be developed. To use the competitive profile matrix and apply the weighted criteria for each indicator might help the local government to analyze the sub-sector division in each district. Another suggestion is that local government also needs to prioritize the area that has the lowest GDP and has the lowest poverty rate to implement the OVOP concept. Some area probably do not need local government supports to build its creative industry, but the area that has the lowest poverty level needs more government assistant to alleviate the poverty through OVOP concept in creative industry.

\section{CONCLUDING REMARK}

The implementation of OVOP means that there is one particular concentrated area/district to produce one product will create economic of scale for the cost of the product. The decrease of the cost will increase product's competitiveness in the market. In the end, competitiveness will resulted in economic sustainability in the long-term, as long as the entrepreneur keeps innovate the product and service-embedded. The implementation of OVOP concept to support local entrepreneurs as well as to create new entrepreneur is expected to alleviate the poverty rate in certain district. It 
is also important for local government to make priority to the district that has the lowest poverty rate, thus the local government support for OVOP implementation should be focused in these districts.

Conflict of interest: none declared.

\section{REFERENCE}

1. De Beukelaer C. The UNESCO/UNDP 2013

Creative Economy Report: perks and perils of an evolving agenda. J Arts Manag Law, Soc

[Internet]. 2014;44(2):90-100. Available from: http://www-tandfonline-

com.ez.sun.ac.za/doi/abs/10.1080/10632921.2014. 895789?src=recsys\#.VZawtO2qqkolnhttp://www.t andfonline.com/doi/abs/10.1080/10632921.2014.8 95789

2. WIPO. The contribution of creative industry for economic growth and development. 2015.

3. UN. Creative industries boost economies and development, shows UN Report [Internet]. 2013 [cited 2013 Nov 14]. Available from: http://www.unesco.org/new/en/media-services/infocus-articles/creative-industries-boosteconomies-and-development-shows-un-report/

4. 2013 Creative Industry Report Special Edition. UNDP; 2013.

5. Fitriyana F, Sofhani T. Pengembangan Bandung kota kreatif melalui kekuatan kolaboratif komunitas. Bandung; 2016.

6. LPPM_Unpad. Bandung Creative Industry Report. Bandung; 2014.

7. Indonesia DPR. Rencana Pengembangan Ekonomi Kreatif Indonesia 2025. Dep Perdagang Republik Indones. 2008;

8. Pengarahan orientasi penyusunan RPJMD Kota Bandung 2014-2018. Bandung;

9. Dinas KUKM dan Perindag. Bandung Creative Industry Report. Bandung; 2013. 


\section{APPENDICES}

Table 1. Creative Industry Economic Contribution Indicator

\begin{tabular}{|c|c|c|}
\hline & INDICATOR & INFORMATION \\
\hline \multicolumn{3}{|c|}{ A. GDP BASIS } \\
\hline 1 & Turnover (Revenue) & The total value of sales \\
\hline 2 & turnover Growth & Annual sales growth \\
\hline 3 & Gross Value Added & The added value of the creative industries sector \\
\hline 4 & growth NTB & Percentage increase in added value year on year \\
\hline 5 & Domestic demand & Total domestic demand for the product of creative industries \\
\hline 6 & Companies consumption & The number of requests the company to the products of creative industries \\
\hline 7 & Public consumption & The number of government requests for creative industry products \\
\hline 8 & Individual consumption & The number of individual requests for creative industry products \\
\hline 9 & Investment & Total investment in the creative industries \\
\hline \multicolumn{3}{|c|}{ B. BASIS OF LABOR } \\
\hline 1 & Number of Workers (Employee) & The number of workers in the creative industries \\
\hline 2 & Number Employer (Employer) & Total employer categories: Fulltime, Freelance, Women, Men \\
\hline 3 & Number of Creative Workers & The number of workers in the creative industries creative activity \\
\hline 4 & Total of non Creative Workers & The number of workers in the creative industries do not do creative activities \\
\hline \multicolumn{3}{|c|}{ C. BASIS OF COMPANY ACTIVITY } \\
\hline 1 & Total Company & The total number of companies in the creative industries \\
\hline 2 & Market share & The total value of the market share held creative industries \\
\hline 3 & Concentration of Ownership & Creative corporate ownership structure \\
\hline 4 & Concentration of Market (Firm) & The market structure of the creative industries \\
\hline \multicolumn{3}{|c|}{ D. BASIS OF INTERNATIONAL TRADE } \\
\hline 1 & Export value & The sales value of creative industry products abroad \\
\hline 2 & Import value & Value product and input of creative products obtained from abroad \\
\hline 3 & Net trade & Difference in export and import \\
\hline 4 & Export value per export destination & The percentage of the value of exports based-on export destination countries \\
\hline 5 & Portions of raw material imported & The percentage of the cost of raw material imports by country of origin \\
\hline \multicolumn{3}{|c|}{ E. OTHER BASIS } \\
\hline 1 & Consumer age & The age of the consumer, to estimate the potential for growth \\
\hline 2 & Substitution of intra-sectoral & Product exchange between sub-sectors in the creative industries \\
\hline 3 & Licence & The number of licenses issued, a brand of creative industries \\
\hline 4 & Award amount obtained & Award such as music and movies \\
\hline 5 & Growth potential & Estimates of potential growth \\
\hline 6 & Copyright earnings & Revenue from copyright \\
\hline 7 & Tax revenue & Tax revenues directly and indirectly from the creative industries \\
\hline 8 & Degree of innovation & The level of innovation: the number of patents registered, $\mathrm{R} \& \mathrm{D}$ performed \\
\hline 9 & Impact on other sectors & The multiplier effect on other industrial sectors \\
\hline
\end{tabular}

(Source: LPPM Unpad, 2014) 
Table 2. Creative Industry Sub-Sector Distribution in Bandung

\begin{tabular}{|c|c|c|c|c|c|c|c|c|c|c|c|c|c|c|c|c|}
\hline DISTRICT & 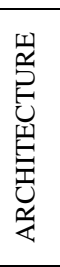 & 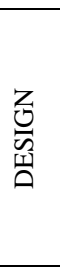 & 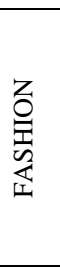 & 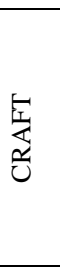 & 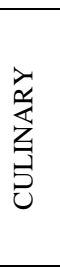 & 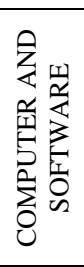 & 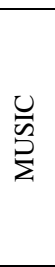 & 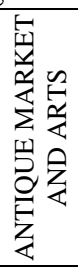 & 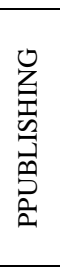 & 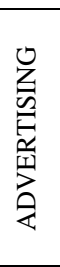 & 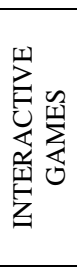 & 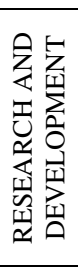 & 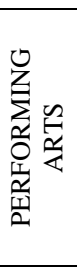 & 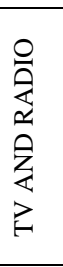 & 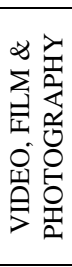 & 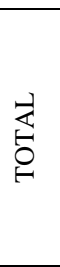 \\
\hline ANDIR & & & 5 & 5 & 5 & & & & & 5 & & & & & & 20 \\
\hline ANTAPANI & 1 & & 13 & 14 & 9 & 1 & & & & 4 & & & & 2 & 1 & 45 \\
\hline ARCAMANIK & 1 & 2 & 3 & 23 & 5 & & & 2 & 1 & & & & & & & 37 \\
\hline ASTANAANYAR & & & 8 & 6 & 4 & & & & & 5 & & & & 1 & & 24 \\
\hline BABAKAN CIPARAY & & 6 & 15 & 34 & 12 & & & & 4 & 1 & & & & & 3 & 75 \\
\hline BANDUNG KIDUL & & & 9 & 11 & 3 & & & 1 & & 2 & & & & & & 26 \\
\hline BANDUNG KULON & & & 11 & 31 & 7 & & & & & 4 & & & & 5 & & 58 \\
\hline BANDUNG WETAN & & 1 & 6 & 20 & 4 & & & 3 & & 6 & & & & 2 & & 42 \\
\hline BATUNUNGGAL & & & 2 & 9 & 5 & & & & & 5 & & & & 2 & & 23 \\
\hline BOJONGLOA KALER & & & 9 & 27 & 6 & & & 1 & & 1 & & & & 1 & & 45 \\
\hline BOJONGLOA KIDUL & & 1 & 2 & 48 & 7 & & & 1 & & 2 & & 1 & & & & 62 \\
\hline BUAHBATU & 1 & & 8 & 12 & 5 & & & & 1 & 4 & & & & & & 31 \\
\hline CIBEUNYING KALER & & & 9 & 12 & 3 & & & 1 & & 4 & & & & 2 & & 31 \\
\hline CIBEUNYING KIDUL & & 6 & 14 & 38 & 13 & & & 1 & & 1 & & & 1 & 4 & & 78 \\
\hline CIBIRU & & & 2 & 2 & & & & & & & & & & & & 4 \\
\hline CICENDO & & 1 & 5 & 16 & 7 & & & & & 2 & & & & 1 & & 32 \\
\hline CIDADAP & & & 6 & 19 & 4 & & & & & 1 & 1 & & & 3 & & 34 \\
\hline CINAMBO & & & & 2 & & & & & & & & & & & & 2 \\
\hline COBLONG & & 3 & 5 & 24 & 3 & & & 1 & 1 & 5 & & & & 8 & & 50 \\
\hline GEDEBAGE & & & 3 & 6 & 1 & & 1 & & & & & & & & 2 & 13 \\
\hline KIARACONDONG & & & 7 & 4 & 6 & & & & & 3 & & & & & & 20 \\
\hline LENGKONG & & 1 & 18 & 24 & 5 & 1 & & 2 & & 17 & & & & 5 & & 73 \\
\hline MANDALAJATI & & & 2 & 10 & 3 & 1 & & & & & & & & & & 16 \\
\hline PANYILEUKAN & & & 2 & 4 & 2 & & & & & & & & & & & 8 \\
\hline RANCASARI & & & 18 & 20 & 9 & 2 & & 1 & & 1 & & & & & & 51 \\
\hline REGOL & & & 11 & 26 & 8 & 1 & & 3 & 1 & 4 & & & & 3 & & 57 \\
\hline SUKAJADI & & 1 & 1 & 18 & 6 & & 1 & 1 & & 6 & & & & 7 & 1 & 42 \\
\hline SUKASARI & & & 7 & 15 & 3 & 1 & & & & 4 & & & & 6 & & 36 \\
\hline SUMUR BANDUNG & & 1 & 1 & 2 & 3 & & & 1 & & 6 & & & 1 & 9 & & 24 \\
\hline UJUNGBERUNG & & 1 & 3 & 6 & 5 & & 1 & 2 & 1 & & & & & & & 19 \\
\hline
\end{tabular}

(Source: Dinas KUKM Bandung, 2013)

Figure 1. OVOP Development Model for Creative Industry

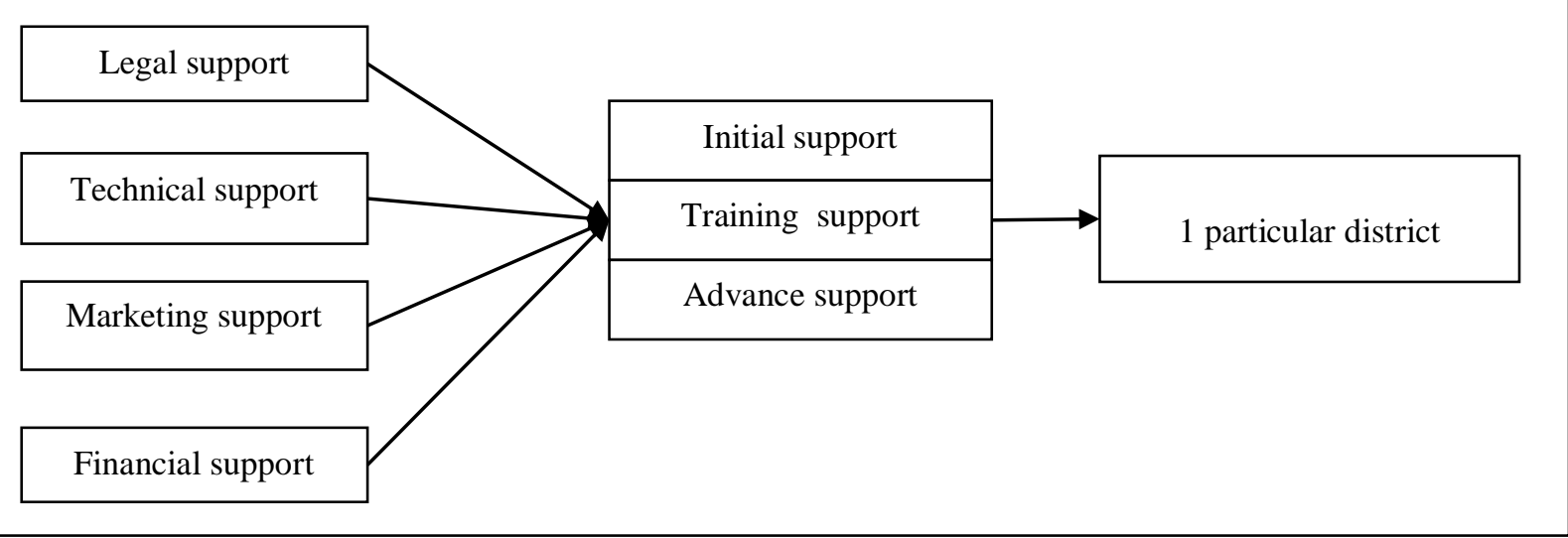

(Source: Adapted from Haraguchi, 2008) 